\title{
Bank Sampah Sebagai Salah Satu Strategis Alternatif Pengelolaan Sampah Berbasis Masyarakat di Desa Sesaot
}

\author{
Handayani Rinuastuti*, Akhmad Saufi, Thatok Asmony, Handry Sudiartha \\ Program Studi Manajemen Fakultas Ekonomi dan Bisnis \\ Universitas Mataram, INDONESIA;
}

\section{Article history}

Received: 25 Maret 2019

Revised: 14 Mei 2019

Accepted: 14 Mei 2019

*Corresponding Author:

Handayani Rinuastuti

Program Studi Manajemen,

Fakultas Ekonomi dan Bisnis

Universitas Mataram, Indonesia

Email*:hrinuastuti@unram.ac.id
Abstract: Plastic waste has become people's main problems in Indonesia, both in cities and rural areas. Sesaot is one of three villages, together with Buwun Sejati and Pakuan Village, developed for sustainable tourist destination. As a tourist icon of Lombok Barat Distric, Sesaot villagers are responsible for keeping the village cleaned. Most people in Sesaot are ignorant of waste management, yet, some efforts are made individually. People are unaware of the economic value of waste management. Waste is percieved as unwanted and discarded residues. Such condition challanges efforts for sustainable tourism. The community service is aimed at directing local communities to participative waste management; encouraging the emergence of collaborative waste management; introducing waste bank model; and initiating the formation of community-based integrated waste management groups. The community service is organised through training and mentoring activities to sellected participants. . Expected results including; (1) the participants acquire knowledge of economic value of waste; (2) the participants form groups to start-up village waste bank.

Keywords: Community service; plastic waste; economic value

Abtrak: Sampah plastik merupakah permasalahan yang dihadapi masyarakat Indonesia tidak hanya di daerah perkotaan, akan tetapi telah merambah di pedesaan. Desa sesaot merupakan salah satu desa yang menjadi kawasan pariwisata berkelanjutan yang berada di Lingkar Sekawan Sejati. Sebagai salah satu ikon pariwisata Kabupaten Lombok Barat, kebersihan menjadi sebuah keharusan yang menjadi tanggung jawab seluruh warga masyarakat. Sebagian besar masyarakat di Desa Sesaot belum sepenuhnya peduli terhadap pengelolaan sampah dan walaupun ada, pengelolaan sampah masih bersifat individual dan belum terorganisir secara terpadu. Masyarakat belum sepenuhnya memahami adanya nilai ekonomis terhadap pengelolaan sampah, karena belum paham terhadap pengelolaan sampah yang mempunyai nilai ekonomis, serta masih menganggap bahwa sampah merupakan sisa dari sebuah proses yang tidak diinginkan dan tidak mempunyai nilai ekonomis. Kegiatan Pengabdian Masyarakat ditujukan untuk mengarahkan masyarakat agar memiliki kesadaran partisipatif akan pengelolaan sampah, menstimulus masyarakat secara umum untuk pengelolaan sampah secara terpadu, dan memperkenalkan pengelolaan sampah melalui Bank Sampah serta mempersiapkan terbentuknya kelompok pengelolaan sampah terpadu berbasis masyarakat. Hasil kegiatan, (1) peserta mendapat pengetahuan dan pengarahan tentang pengelolaan sampah plastik secara ekonomis, (2) terbentuknya kelompok persiapan Bank Sampah

Kata Kunci: layananan masyarakat; sampah Plastik; niai ekonomis 


\section{PENDAHULUAN}

Edukasi masyarakat mengenai permasalahan lingkungan yang bersifat kompleks akibat timbulan sampah diperlukan untuk membentuk kesadaran masyarakat. Partisipasi aktif warga menjadi hal yang penting untuk diidentifikasikan dalam aksi pengelolaan sampah. Upaya menjaga kelestarian lingkungan harus bermula dari diri individu dengan memulai melakukan hal-hal kecil. Perubahan yang dilakukan kemudian dapat 'ditularkan' menjadi kebiasaan dalam keluarga ataupun masyarakat, sehingga terjadi perubahan besar. Menurut Singhirunnusorn dkk. (2012), perubahan cara berpikir masyarakat mengenai pengelolaan sampah rumah tangga untuk mengurangi sampah di sumber melalui partisipasi warga harus diintegrasikan ke dalam proyek bank sampah yang berbasis masyarakat.

Sesuai dengan ketetapan dalam Undang Undang Nomor 18 Tahun 2008 tentang Pengelolaan Sampah, kini perlu perubahan cara pandang masyarakat mengenai sampah dan cara memperlakukan atau mengelola sampah. Cara pandang masyarakat pada sampah seharusnya tidak lagi memandang sampah sebagai hasil buangan yang tidak berguna. Sampah seharusnya dipandang sebagai sesuatu yang mempunyai nilai guna dan manfaat. Dalam rangka melaksanakan Peraturan Pemerintah No. 81 Tahun 2012 tentang Pengelolaan Sampah Rumah Tangga dan Sampah Sejenis Sampah Rumah Tangga, maka praktek mengolah dan memanfaatkan sampah harus menjadi langkah nyata dalam mengelola sampah (Anonim KLH; 2012). Masyarakat harus meninggalkan cara lama yang hanya membuang sampah dengan mendidik dan membiasakan masyarakat memilah, memilih, dan menghargai sampah sekaligus mengembangkan ekonomi kerakyatan melalui pengembangan bank sampah (Triana dkk, 2013).

Pada dasarnya bank sampah merupakan konsep pengumpulan sampah kering dan dipilah serta memiliki manajemen layaknya perbankan, tetapi yang ditabung bukan uang melainkan sampah. Warga yang menabung (menyerahkan sampah) juga disebut nasabah dan memiliki buku tabungan serta dapat meminjam uang yang nantinya dikembalikan dengan sampah seharga uang yang dipinjam. Sampah yang ditabung akan ditimbang dan dihargai dengan sejumlah uang, kemudian akan dijual di pabrik yang sudah bekerja sama dengan bank sampah.

Untuk alternatif solusi dalam mengatasi masalah sampah, pengembangan bank sampah merupakan kegiatan bersifat social engineering (Ridley-Duff dan Bull, 2011 dalam Kristina dkk, 2014) yang mengajarkan masyarakat untuk memilah sampah serta menumbuhkan kesadaran masyarakat dalam pengolahan sampah. Pembentukan bank sampah harus diintegrasikan dengan gerakan program 4R sehingga warga akan memperoleh manfaat langsung, tidak hanya secara ekonomi, juga terwujudnya kesehatan lingkungan, dengan kondisi komunitas yang bersih, hijau, nyaman, dan sehat. Selain itu, bank sampah memberikan manfaat secara sosial dengan memperkuat kohesi sosial. Manfaat lainnya secara ekonomis memberi dampak berupa tambahan penghasilan, dan manfaat untuk lingkungan dapat mengurangi timbulan sampah.

Desa sesaot merupakan salah satu desa yang menjadi kawasan pariwisata berkelanjutan yang berada di Lingkar Sekawan Sejati (Desa Sesaot, Desa Pakuwan, dan Desa Buwun Sejati). Dengan jumlah penduduk yang tertinggi diantara dua desa lainnya yakni sebanyak 5.661 jiwa atau $1.810 \mathrm{KK}$ serta memiliki obyek wisata hutan lindung dan taman Aik Nyet, yang banyak dikunjungi oleh masyarakat dari luar desa bahkan luar kabupaten Lombok Barat. Kondisi ini menjadikan Desa Sesaot sebagai desa yang cukup padat penduduk dan pengunjungnya, dengan aktivitas masyarakat yang cukup tinggi, sehingga timbulan sampah dari aktivitas masyarakat tersebut relatif tinggi.

Secara sosial, sebagian besar masyarakat di Desa Sesaot belum sepenuhnya peduli terhadap pengelolaan sampah dan walaupun ada pengelolaan sampah masih bersifat individual dan belum terorganisir secara terpadu, sehingga intensitas kebersamaan dalam komunitas masih sangat rendah. Kemudian secara ekonomi, saat ini belum ada nilai ekonomis terhadap pengelolaan sampah, selain masyarakat belum paham terhadap pengelolaan sampah yang mempunyai nilai ekonomis dengan $4 \mathrm{R}$ (reduce, reuse, recycle dan replant). Sebagian besar kesadaran terhadap pengelolaan sampah masih rendah dikarenakan masyarakat masih menganggap bahwa sampah merupakan sisa dari sebuah proses yang tidak diinginkan dan tidak mempunyai nilai ekonomis. 
Sebagai desa yang menjadi salah satu ikon wisata Kabupaten Lombok Barat, kondisi ini tentunya akan berdampak negatif bagi keberlangsungan kegiatan pariwisata. Timbulan sampah yang tidak dikelola dengan baik yang berasal dari aktivitas masyarakat maupun pengunjung akan mengurangi kenyamanan, lingkungan menjadi kotor, timbulnya berbagai macam penyakit, pencemaran lingkungan dan kerusakan ekosistem. Terlebih lagi masih adanya masyarakat yang membuang sampah bukan pada tempatnya dan bahkan membuang ke sungai/ membakarnya. Hal ini akan memberikan kesan negatif bagi desa tersebut sebagai sebuah destinasi wisata, yang dapat berdampak pada keberlanjutan desa Sesaot sebagai sebuah destinasi wisata.

Oleh karena itu tujuan dari kegiatan Pengabdian adalah mengarahkan masyarakat untuk memiliki kesadaran partisipatif akan pengelolaan sampah, menstimulus masyarakat secara umum untuk pengelolaan sampah secara terpadu, serta memperkenalkan pengelolaan sampah melalui Bank Sampah serta mempersiapkan terbentuknya kelompok pengelolaan sampah terpadu berbasis masyarakat.

\section{METODE}

Kegiatan Pengabdian kepada Masyarakat ini dilakukan melalui serangkaian tahapan kegiatan yang meliputi pelatihan, dilanjutkan dengan pendampingan dan evaluasi. Kegiatan pelatihan tersebut dilakukan dengan penyampaian materi dalam bentuk ceramah dan diskusi, tentang pengenalan cara pengelolaan sampah, pemilahan sampah, bank sampah sebagai alternatif strategi pengelolaan sampah berbasis masyarakat, serta berbagai alternatif pengolahan sampah yang bernilai ekonomis. Nara sumber adalah Tim Pengabdian Masyarakat dan berkoordinasi dengan aparat Desa Sesaot.

Pendampingan, dilakukan melalui fasilitator dan pembinaan dalam mempersiapkan pembentukan Bank sampah pada satu kelompok persiapan yakni kelompok pemuda Desa Sesaot. Evaluasi keberhasilan kegiatan dilakukan dengan melihat tanggapan peserta dan kemampuan kemampuan penguasaan materi dalam kegiatan pelatihan, dan terbantuknya kelompok persiapan bank sampah yang dikelola secara mandiri oleh masyarakat

\section{HASIL DAN PEMBAHASAN}

\section{Pelatihan}

Sebagai langkah awal dalam kegiatan pengabdian, dilakukan pelatihan melalui ceramah, tanya jawab dan diskusi. Pelatihan merupakan tahap penyadaran dan pembentukan perilaku menuju perilaku sadar dan peduli, dan merupakan tahap transformasi kemampuan berupa wawasan pengetahuan, kecakapan-keterampilan agar terbuka wawasan, dan memberikan keterampilan dasar. Selain itu pada tahapan ini diharapkan dapat meningkatkan kemampuan intelektual dan kecakapan-keterampilan, sehingga terbentuk inisiatif dan kemampuan inovatif untuk mengantarkan pada kemandirian.

Materi yang diberikan dalam pelatihan antara lain tentang Pengelolaan Sampah Plastik yang bernilai ekonomis, Pengenalan Bank Sampah, serta manajemen Bank Sampah. Materi diberikan dengan bahasa yang mengena dan mudah dimengerti masyarakat umum, dan didukung dengan bantuan LCD sehingga dapat menarik perhatian peserta. Selain pemberian materi, pelatihan dilanjutkan melalui diskusi dan tanya jawab, sehingga dapat mengamati antusiasme dan tingkat daya serap peserta terhadap materi yang disampaikan.

Peserta pelatihan sebanyak 30 orang, sebagian besar merupakan pemuda desa Sesaot, sehingga diharapkan dapat menjadi inisiator bagi terbentuknya bank Sampah. Umumnya peserta cukup mengetahui pentingnya menjaga kebersihan lingkungan, bahaya dari sampah plastik, walaupun masih minim. Sebagian besar peserta belum sepenuhnya memahami bahwa pengelolaan sampah yang baik melalui Bank sampah dapat memberikan manfaat ekonomis bagi masyarakat, bagaimana proses pembentukannya, manajemen, serta hal-hal lain terkait dengan bank sampah. Peserta setuju untuk 
merubah cara pikir dan menambah wawasan mereka terutama terkait pengetahuan yang didapat dari pelatihan terutama dalam pengelolaan sampah.
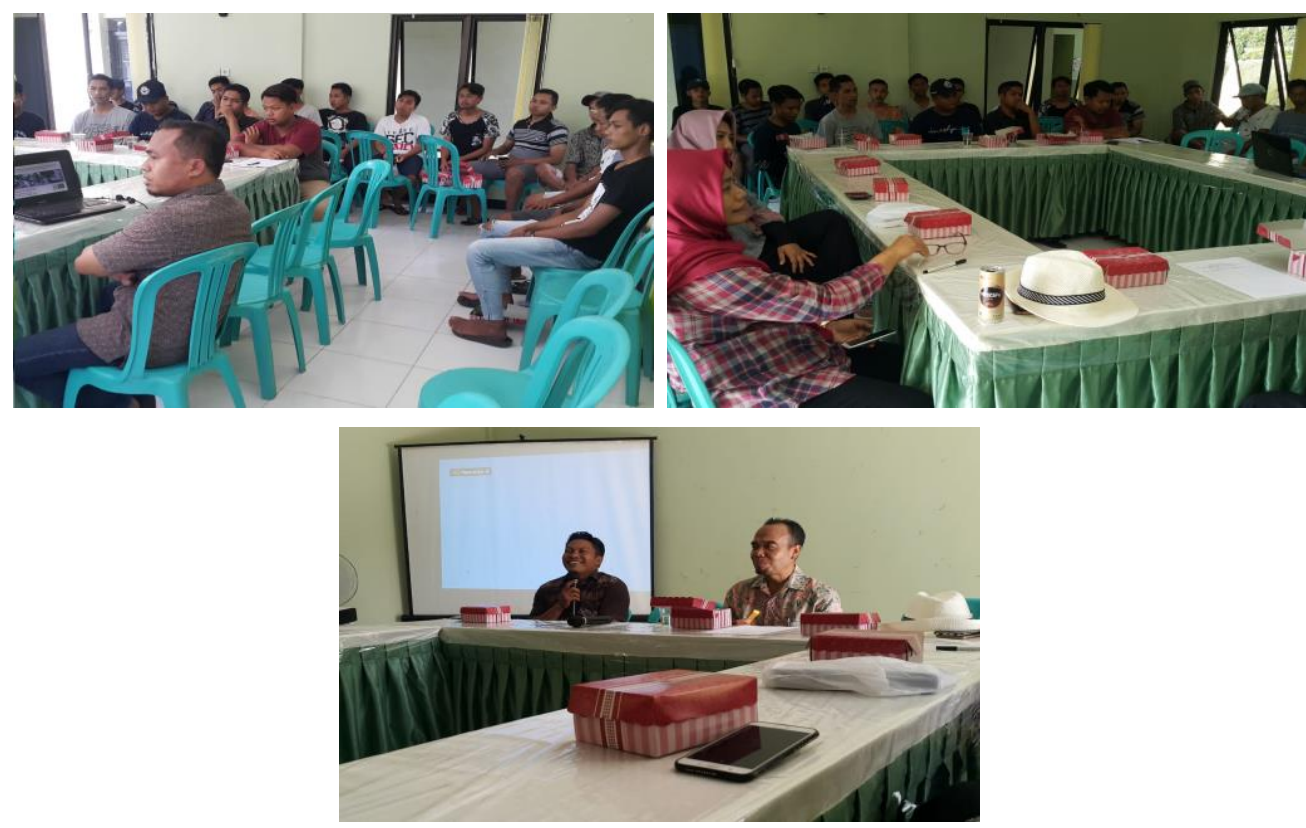

Gambar. Pelaksanaan kegiatan pelatihan

\section{Pendampingan}

Untuk memberikan penguatan terhadap materi yang telah diberikan, maka dibentuk kelompok masyarakat khususnya pemuda sebagai persiapan terbentuknya Bank Sampah. Selama satu bulan dilakukan berbagai pendampingan mulai dari persiapan organisasi, sumber daya manusia yang diperlukan, serta bagaimana manajemen yang perlu diterapkan dalam bank sampah. Pendampingan ini dilakukan dengan memberikan bimbingan, menjawab pertanyaan-pertanyaan yang mungkin muncul terkait kendala yang dihadapi peserta dalam mengaplikasikan materi pelatihan yang telah diberikan.

Peserta menunjukkan keseriusan dan semangat yang cukup tinggi untuk mengembangkan bank sampah sebagai salah satu alternatif pengelolaan sampah yang berbasis partisipasi masyarakat, serta memberikan nilai ekonomis bagi pelakunya. Dengan demikian diharapkan keberlanjutan dari kegiatan ini adalah terbentuknya Bank Sampah yang dapat menjadi solusi dalam pengelolaan masalah sampah di Desa Sesaot.
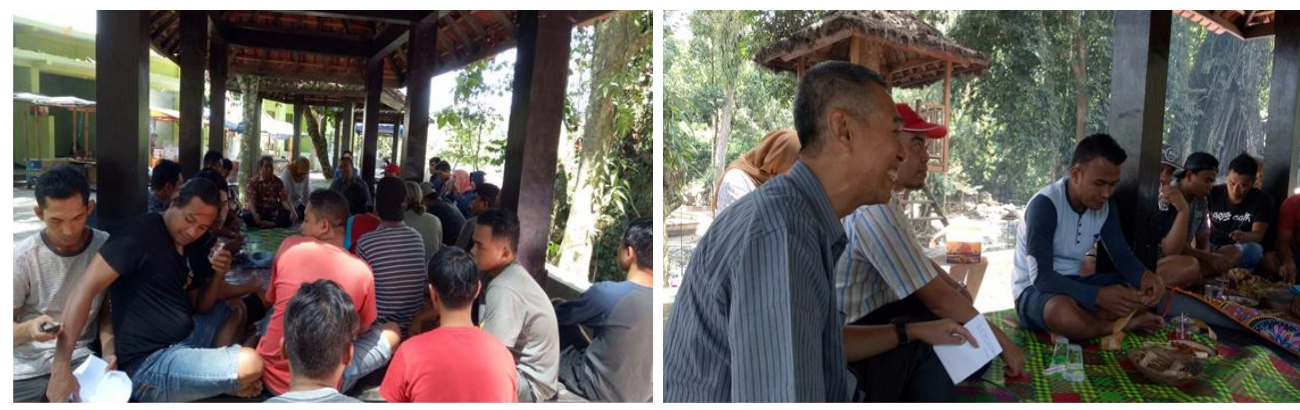

Gambar. Suasana pelaksanaan kegiatan pendampingan 


\section{Evaluasi}

Evaluasi dilakukan pada setiap tahapan kegiatan, sehingga dapat menjadi indikator dalam mengukur keberhasilan kegiatan pengabdian ini. Dalam Pelatihan dilakukan dengan melihat antusiasme peserta, dan keaktifan mereka dalam melakukan diskusi. Pada Kegiatan Pendampingan, evaluasi dilakukan dengan menilai kemampuan peserta dalam mengaplikasikan berbagai materi pelatihan serta semangat dan komitmen dari peserta guna terbentuknya Bank Sampah ke depannya.

Dari seluruh proses kegiatan yang telah dilaksanakan secara umum peserta sangat antusias dan bersemangat dalam menerima materi-materi yang diberikan. Selama ini mereka belum mengetahui bahwa sampah jika dikelola dengan baik dapat memberikan tambahan penghasilan, bahkan dengan manajemen yang baik bisa membentuk Bank Sampah. Peserta berperan aktif dalam pelatihan dan pendampingan, mereka menunjukkan kerjasama tim yang baik serta kemauan yang cukup tinggi untuk berperan aktif dalam pengelolaan sampah. Tim pengabdian tidak menemukan kendala yang cukup berarti dalam pelaksanaan kegiatan, karena adanya komunikasi yang baik antara tim dengan pemerintah desa serta tokoh masyarakat di Desa Sesaot.

\section{KESIMPULAN DAN SARAN}

Kegiatan pengabdian kepada masyarakat ini merupakan kegiatan yang sangat bermanfaat dan menambah pengetahuan masyarakat desa dalam rangka meningkatkan partisipasi dan pemberdayaan masyarakat khusunya pemuda di Desa Sesaot. Respon peserta yang positif menunjukkan keinginan yang kuat dalam upaya mengelola sampah plastik yang dapat memberikan nilai ekonomis bagi masyarakat. Diharapkan dengan adanya pemahaman peserta akan pentingnya pengelolaan sampah dapat disebarluaskan kepada masyarakat di Desa Sesaot, sehingga masyarakat luas memiliki pemahaman akan arti pentingnya menjaga kebersihan serta berperan aktif dalam menjaga lingkungan sekitarnya. Oleh karena itu diperlukan keberlanjutan kegiatan dalam mewujudkan Bank Sampah sebagai salah satu alternatif solusi manajemen sampah yang merupakan wujud nyata partisipatif masyarakat luas dalam menjaga lingkungannya.

\section{Ucapan Terima Kasih}

Kegiatan pengabdian ini dapat berlangsung atas bantuan banyak pihak. Dalam kesempatan ini tim pelaksana menyampaikan ucapan terima kasih kepada Universitas Mataram yang telah memberikan pendanaan kegiatan, Bapak Syawaludin, SE sebagai salah satu nara sumber, Aparat Pemerintah serta masyarakat Desa Sesaot yang telah mendukung dan mensukseskan kegiatan ini.

\section{DAFTAR PUSTAKA}

Anonim, 2012. Profil Bank Sampah Indonesia 2012. Kementerian Lingkungan Hidup, Jakarta.

Kristina, H., 2014. Model Konseptual Untuk Mengukur Adaptabilitas Bank Sampah di Indonesia. Jurnal Teknik Industri, 9(1):19-28.

Singhirunnusorn, W.,Donlakorn, K., dan Kaewhanin, W., 2012. Household Recycling Behaviours and Attitudes toward Waste Bank Project: Mahasarakham Municipality. Journal of Asia Behavioural Studies, 2(6):35-47.

Trina, E., Tallei, T.E., Iskandar, J., Runtuwene, S., dan Filho, W.L., 2013. Local Community- based Initiatives of Waste Management Activities on Bunaken Island in North Sulawesi, Indonesia. Research Journal of Environmental and Earth Sciences, 5(12):737-743.

Winarso, H., dan Larasati, A., 2011. Dari Sampah Menjadi Upah: Inovasi Pengolahan Sampah di Tingkat Akar Rumput Kasus Program Bank Sampah "Sendu" di Kelurahan Pasar Minggu Jakarta Selatan. Jurnal Manusia dan Lingkungan, 18(1):43-59 